\title{
INFLUENCE OF FRICTION CONDITION ON FAILURE LOCATION OF AA5754 ALUMINIUM SHEET IN NAKAJIMA TEST
}

\begin{abstract}
This paper presents the results of numerical and experimental investigations on the influence of friction on failure location in Nakajima formability tests. Finite element (FE) simulations were performed using commercial explicit dynamic FE code. The numerical results obtained from the FE simulation were compared with experimental data from Nakajima tests. A 3D digital image correlation system ARAMIS was used in experiments. The location of failure on the sample was detected depending on friction conditions. The studies confirmed that the crack location near the centre of the specimen as required by the ISO standard could be obtained for low values of the friction coefficient. The numerical simulation combined with the inverse analysis was used to estimate a real value of the friction coefficient in the Nakajima formability test.
\end{abstract}

Keywords: Nakajima test, friction, strain paths, failure, FE simulation

\section{Introduction}

Aluminium alloys are used in automotive structural applications because of their combination of density, strength, and formability. Thus, the use of aluminium and the associated weight reduction significantly improves the fuel economy of the vehicles. An important technological feature of these sheets is the formability [1]. Sheet metal formability is the ability of the sheet to undergo deformation without defects and still belongs to the main scope of research in sheet forming. Even if there are many concepts of formability prediction, strain based forming limit diagrams (FLDs) are most often used in engineering practice to evaluate the sheet formability [2]. In metal forming operations the forming limit curve (FLC) is frequently selected as the formability limit because both localized deformation and extreme thickness reduction may compromise the part utility. The FLC is widely plotted as a single curve which represents the beginning of

\footnotetext{
1 Autor do korespondencji/corresponding author: Jan Slota, Technical University of Košice, Mäsiarska 74, 04001 Košice, Slovakia, e-mail: jan.slota@tuke.sk

${ }^{2}$ Marek Šiser,Technical University of Košice, e-mail: marek.siser@tuke.sk
} 
plastic instability, or by definition it delineates the boundary of uniform straining and the onset of local necking. The region under this curve corresponds to admissible deformation while the upper region usually represents undesirable deformation. The location of the points representing principal strains concerning the FLC allows determining the probability of defects in the form of necking or sheet metal fracture. Formability of metal sheets is studied experimentally using various tests, including uniaxial tensile test, hydraulic bulge test, different hemispherical dome tests such as Erichsen [3], Nakajima [4] or punch stretching methods such as Marciniak test [4].

To determine the formability of sheet metals, the FLCs, determined by using formability tests, are used. These curves define the safe conditions of deformation regarding principal strains. In the punch stretching test the specimen is stretched using a punch until the occurrence of fracture. Different specimen geometry leads to various strain paths. Formability tests results are influenced by friction or, in general, by the tribological properties between the tool and the specimen. Friction changes the location of failure and strain paths in a tested specimen. Strain paths influenced by friction are an undesired phenomenon in forming tests, therefore different measures are taken to reduce friction. In the Nakajima test, either oil, grease or polymer foils should be used as lubricant systems. Friction conditions should be adjusted so that fracture occurs within a distance less than $15 \%$ of punch diameter away from the centre of the specimen [4]. Using zero friction, we can locate a failure in the centre of the sample with strain paths at the fracture point. Failure location is very dependent on friction conditions. Even small friction can lead to an increase the displaces of the fracture location $[2,5]$. The aim of this study is to investigate the influence of friction conditions on fracture location during Nakajima test and their influence on strain paths in the specimen.

To improve the quality of sheet metal forming analysis, some works on failure analysis have been reported by the authors in [5-7]. In these works, various procedures for limit strain prediction are discussed, such as theoretical/analytical methods, experimental methods, and FE simulations. Special attention is paid to the material modelling, the effect of element size, and the impact of friction on the failure behaviour of sheet metal. It was shown that the limit strains from the numerical simulations are dependent on the resolution of the finite element mesh during the neck creation phase. Furthermore, it is shown how material data have some impact on the results, and also how small changes in friction conditions also impact the origin of the failure. To compare the resulting limit strains, Nakajima tests were simulated. Considerable differences between the predicted FLC results by the various modelling options were observed. These facts illustrate the complexity of the problem. 


\section{Objectives and approach}

The Nakajima test represents a stretching operation up to fracture which is used for the determination of forming limit diagrams. The tools used in the Nakajima test include a hemispherical punch, a blankholder, and a die. In this study, seven simulations with different blank specimens with widths of the middle section of 45, 60, 75, 90,110, 130 and $180 \mathrm{~mm}$ are conducted. The major and minor principal strains recorded at the end of each of these simulations correspond to a point on the FLD.

Nakajima type formability tests were carried out for the aluminium alloy sheets mostly used in automotive industry for stamping of car body parts. Figure 1 shows the geometry of the tool and specimens used in the tests. The use of specimens of different widths allows us to obtain failure for different strain paths. These tests were performed with lubricant according to standard ISO 12004$2: 2008$. The objective of the numerical simulations was to identify value of the friction coefficient in the test and study its effect on the location of the fracture. The value of the friction coefficient significantly depends on fracture location on the tested sample. For this experiment, an automotive sheet from the aluminium alloy was used. The specimens were made of AA5754 H11 aluminium alloy sheet with the thickness of $0.8 \mathrm{~mm}$. This sheet was supplied in the form of a rolled sheet produced by hot and cold rolling, andsubjected to H11-temper i.e., annealing at $340^{\circ} \mathrm{C}$ for two hours followed by air cooling. The chemical composition of the AA5754 H11 aluminium alloy is listed in Tab. 1. Basic mechanical properties of the sheet material are listed in Tab. 2.

Table 1. Chemical composition of the AA5754 H11 aluminium alloy

\begin{tabular}{|c|c|c|c|c|c|c|c|c|c|}
\hline Element & $\mathrm{Si}$ & $\mathrm{Fe}$ & $\mathrm{Cu}$ & $\mathrm{Mn}$ & $\mathrm{Mg}$ & $\mathrm{Cr}$ & $\mathrm{Zn}$ & $\mathrm{Ti}$ & $\mathrm{Al}$ \\
\hline wt.\% & 0.4 & 0.4 & 0.1 & 0.5 & $2.6-3.6$ & 0.3 & 0.2 & $<0.15$ & balance \\
\hline
\end{tabular}

Table 2. Mechanical properties of the AA5754 H11 aluminium alloy

\begin{tabular}{|c|c|c|c|c|c|c|}
\hline $\begin{array}{l}\text { Specimen } \\
\text { orientation }\end{array}$ & $\begin{array}{c}\mathrm{R}_{\mathrm{p} 0.2}(\mathrm{Re}) \\
{[\mathrm{MPa}]}\end{array}$ & $\begin{array}{c}\mathrm{R}_{\mathrm{m}} \\
{[\mathrm{MPa}]}\end{array}$ & $\begin{array}{l}\mathrm{A}_{80} \\
{[\%]}\end{array}$ & $\begin{array}{c}\mathrm{n} \\
{[-]}\end{array}$ & $\begin{array}{c}\mathrm{C}_{\mathrm{m}} \\
{[\mathrm{MPa}]}\end{array}$ & $\begin{array}{c}\mathrm{r} \\
{[-]}\end{array}$ \\
\hline $0^{\circ}$ & 146 & 231 & 19.6 & \multirow{3}{*}{0.283} & \multirow{3}{*}{438.28} & 0.655 \\
\hline $45^{\circ}$ & 136 & 220 & 26.1 & & & 0.904 \\
\hline $90^{\circ}$ & 137 & 222 & 25.4 & & & 0.723 \\
\hline
\end{tabular}

A diameter of specimens was $205 \mathrm{~mm}$ and all of them were cut parallel to the rolling direction, as shown in the Fig. 1. Nakajima formability tests were carried out on universal sheet metal testing machine Erichsen 145-60 (Fig. 2) with non-contact measuring system based on digital image correlation. Experimental 
results were compared with FEM simulation. The dynamic explicit code was used to predict the position of failure and various friction values were set in FEM code. Combined triangular and quadrilateral element type was used in both tool and blank mesh. The parameters set in the numerical model of formability test are described in the Tab. 3. It is known [8] that the limit strains determined in the FE simulations are dependent on the resolution of the finite element mesh. So, special attention should be paid to the effect of element size. The importance of material modelling and the impact of friction on the failure behaviour deserves proper attention.
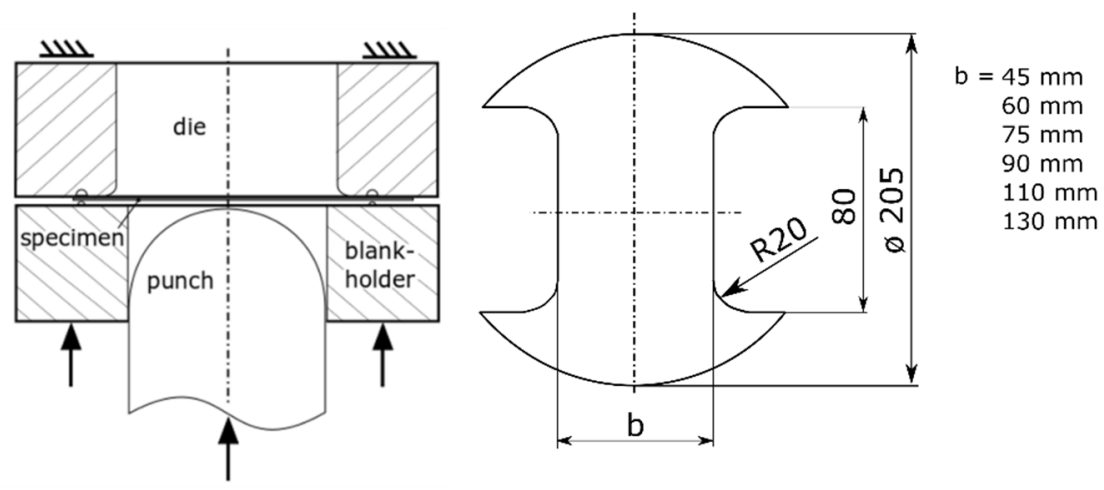

Fig. 1. Experimental tool (left) and dimensions of specimens (right) used for determination of the forming limit curve

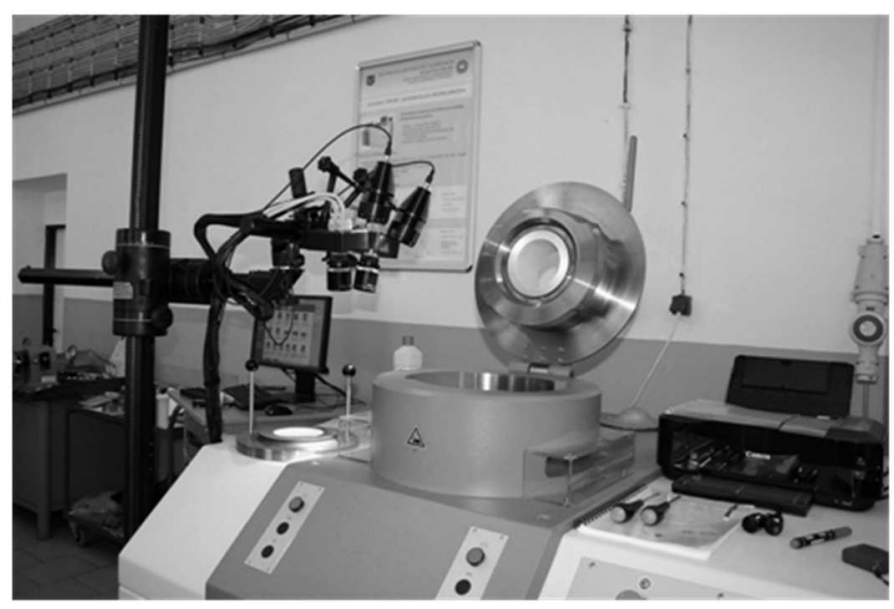

Fig. 2. Universal test machine Erichsen 145-60 with ARAMIS system 
Table 3. Parameters defined in the numerical model

\begin{tabular}{|l|c|l|c|}
\hline \multicolumn{1}{|c|}{ Parameter } & \multicolumn{1}{c|}{ Value } & \multicolumn{1}{c|}{ Parameter } & Value \\
\hline Mesh type & Triangular/Quadrilateral & Element type & Shell \\
\hline Mesh size & $4 \mathrm{~mm}$ & Friction coefficient & Variable \\
\hline Level of refinement & 3 & Yield curve & Vegter-Lite \\
\hline Mesh size after refinement & $0.5 \mathrm{~mm}$ & Hardening curve & Krupkowski \\
\hline Number of integration points & 5 & Tool mesh & $0.5 \mathrm{~mm}$ \\
\hline
\end{tabular}

\section{Results and discussion}

Nakajima formability tests were carried out for all type of specimens. The mean surface roughness of sheets used in the experiment was $R_{a}=0.3 \mu \mathrm{m}$. Total height of the profile was $\mathrm{R}_{t}=1.7 \mu \mathrm{m}$. In tests, 0.5 -mm-thick PTFE foil and grease were used to decrease friction conditions between hemispherical punch and specimen. The diameter of the punch is $100 \mathrm{~mm}$. Seven samples with a width range from 45 to $180 \mathrm{~mm}$ have been used to build the FLC. The specimens after Nakazima tests used in comparison with the numerical results are presented in Fig. 3. The strains on the surface of specimens have been measured using the ARAMIS system (GOM, Germany). The experimental FLC was built using the ARAMIS system according to ISO 12004:2008 standard [4]. The fractures of the samples were located in the centre, respectively in the close area and all fractures meet the conditions specified in the relevant standard [4]. This means, that they were located within the defined range of $15 \%$ from centre (pole) of the specimen.

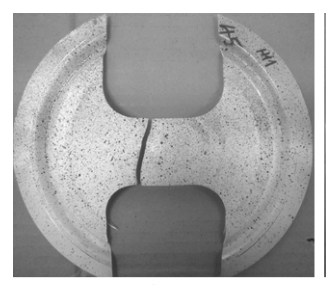

a)

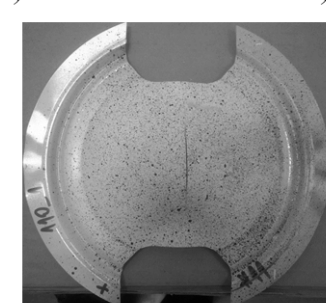

e)

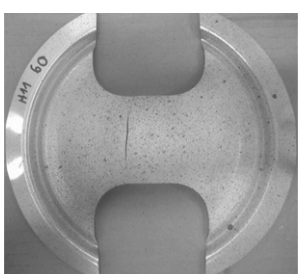

b)

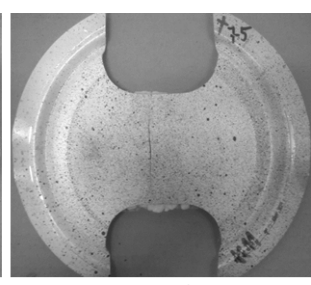

c)

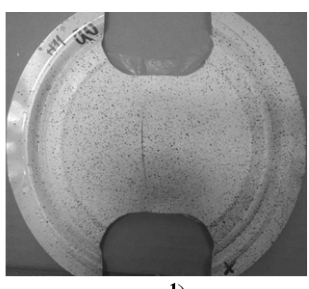

d)

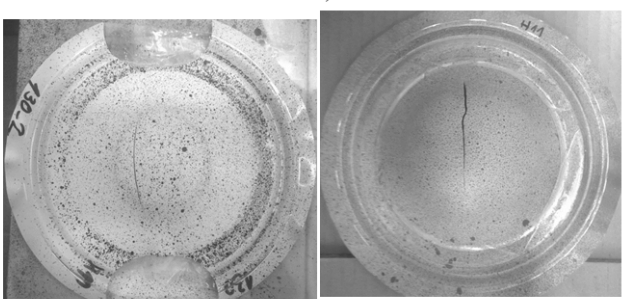

f)

g)

Fig. 3. Fractured surfaces of AA5754 H11 specimens with different width (in mm): a) 45, b) 60, c) 75 , d) 90 , e) $110, \mathrm{f}) 130, \mathrm{~g}$ ) circular with diameter of $180 \mathrm{~mm}$ 
The FE simulations were performed using explicit dynamic finite element code. The tested sheets were discretized with the quadrilateral shell elements. The material was considered assuming the Vegter lite constitutive model with planar anisotropy. The hardening curves were extrapolated with Krupkowski (Swift) power law. The numerical simulations were performed for all type of specimens according to Fig. 1. The level of stamping at which the failure, in the form of necking, is achieved in the numerical simulation was assessed using section method. Determination of the onset of localized necking was shown for all specimens and evolution of the major principal strains in the failure zone of this specimen is given in Fig. 4a-g.

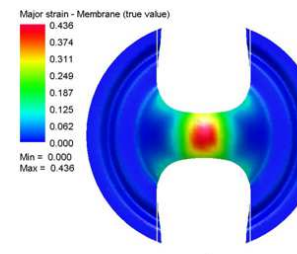

a)

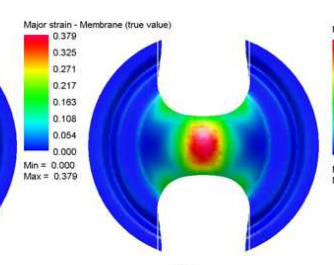

b)

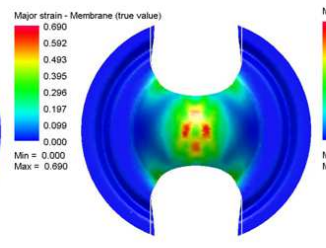

c)

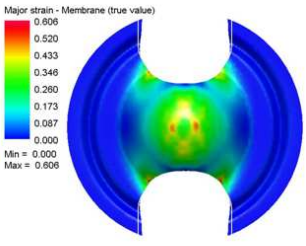

d)

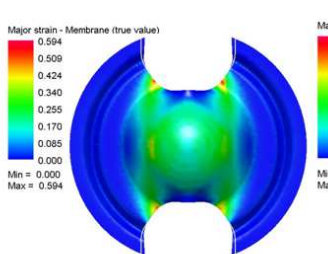

e)

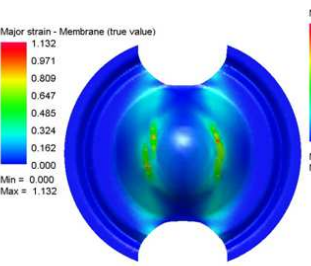

f)

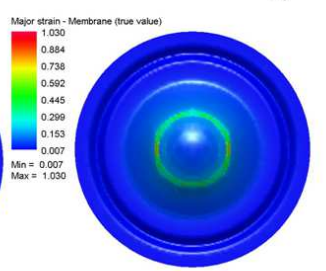

g)

Fig. 4. Major principal strain distribution on specimens of different geometry (width in mm): a) 45 , b) 60 , c) 75 , d) 90 , e) 110, f) 130, g) circular with diameter of $180 \mathrm{~mm}$

The critical strain values were similarly achieved in the experiment. The strain path for the most deformed areas of these samples to the critical area was indicated in the FLD, and is shown in Fig. 6. To obtain strain paths as close as possible to experimental strain paths, the calibration procedure was performed. Friction conditions between punch and sheet were analysed for several friction coefficient values and through the inverse analysis it was found, that for specimen with width of $110 \mathrm{~mm}$, friction coefficient answered the value of friction coefficient $\mu=0.05$ and for the full circular specimen $\mu=0.04$. The values of limit strains achieved numerically were compared with limit strains obtained experimentally and with FLC. The values of the numerically obtained strain paths were quite similar to the experimental FLC for strain paths close to the plain strain. The experimental strains obtained by the criterion are close to the values of strains before the fracture. The numerical results of the Nakajima simulations with the minor principal strain distribution are depicted in Fig. 5a-g.

The various friction conditions change strain paths and failure location in the specimen. Changes in strain paths dependent on friction are shown in Fig. 6. 
Constant friction can often produce reliable results. However, the value of the constant Coulomb friction coefficient is unknown in advance and must be inversely modelled by studying the output from a real die or applied with extensive experience, often adapted based on a trial-and-error approach. Therefore, one of the main reasons for a physically-based friction model is to predict the friction conditions in a simulation before a die is fabricated $[9,10]$.

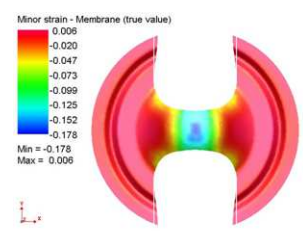

a)

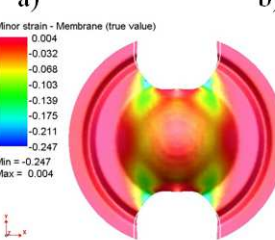

e)

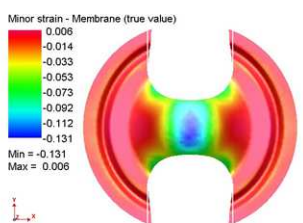

b)

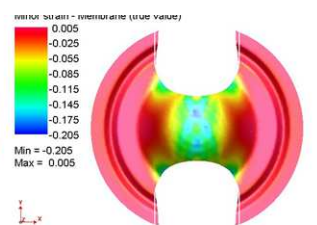

c)

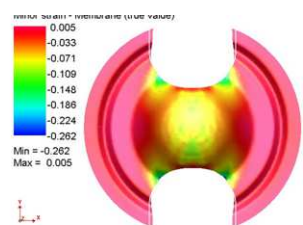

d)

Fig. 5. Minor principal strain distribution on specimens of different geometry (width in $\mathrm{mm}$ ) a) 45 , b) 60 , c) 75 , d) 90 , e) 110, f) 130 , g) circular with diameter of $180 \mathrm{~mm}$

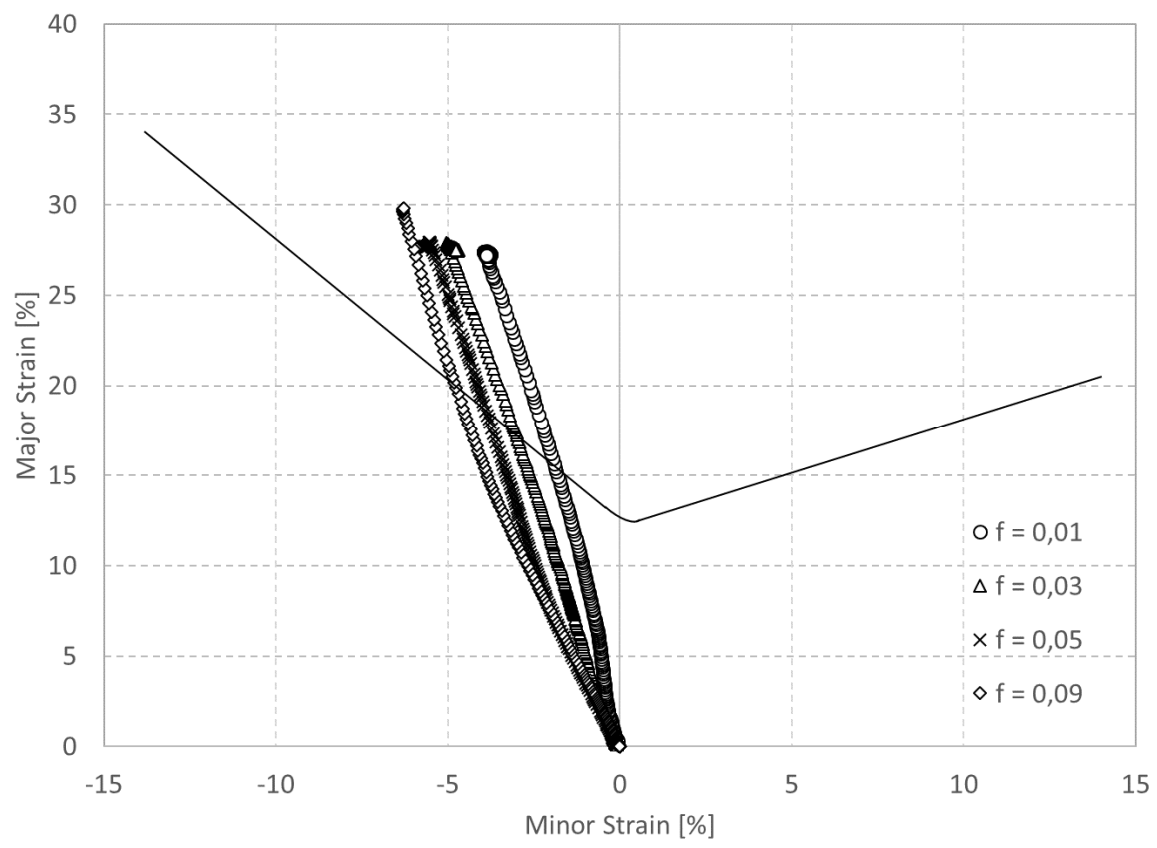

Fig. 6. Comparison of experimental FLC with simulated strain paths of 110-mm-width specimen with the different coefficient of friction 


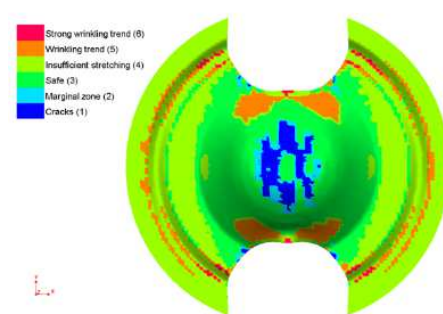

a) $\mathrm{f}=0.01$

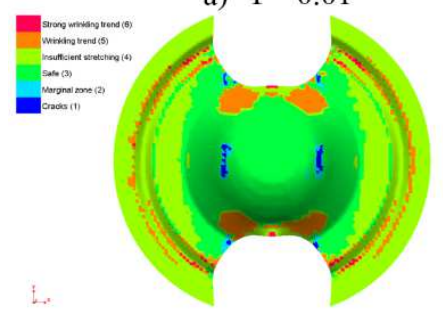

c) $\mathrm{f}=0.05$
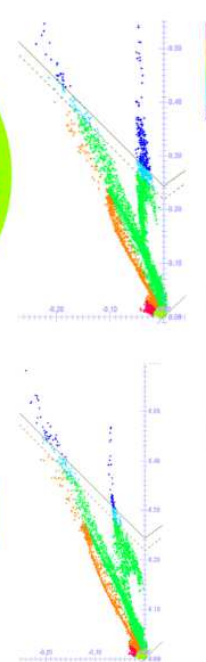

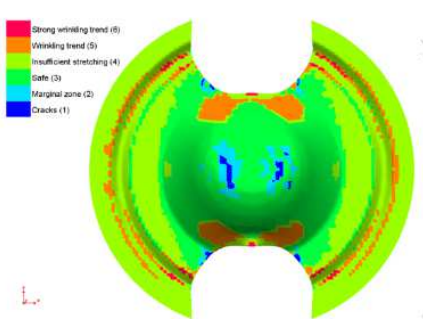

b) $f=0.03$

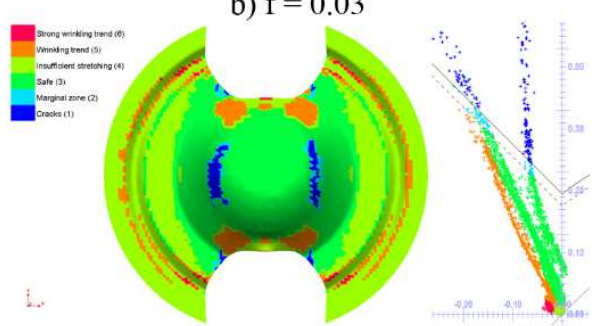

c) $\mathrm{f}=0.1$

Fig. 7. Effect of the value of friction coefficient on the location of failure area in the Nakajima test

One of the goals of FE simulations was to determine the value of friction coefficient obtained in the real experiment. For this reason, FE simulations were performed with friction coefficients range from 0.01 to 0.1 , graded at 0.01 . From the results, it is clear that the closest to the real experiment was the results obtained with friction coefficients of 0.04 to 0.05 . Figure 7 shows the FE simulation results with the different coefficient of friction on a $110 \mathrm{~mm}$ specimen at the end phase of the test. In general, it can be seen that the numerical FLC overestimate critical strains determined experimentally. This is understandable, since different failure criteria can lead to different FLCs. For example, according to [5, 7], the criteria of the time dependent methods predict higher critical strains than other methods.

\section{Conclusion}

The analysis of numerical results obtained in simulations of Nakajima tests performed for the selected specimens confirms the validity of the numerical model. The numerical prediction of the strain distribution and failure is close to the experimental results. Results presented in this paper allow the following conclusions to be drawn:

- The friction coefficient greatly affects the failure location. With a decreasing the friction coefficient value, the location of failure is closer to the apex of a dome. It should be noted that a constant friction coefficient was specified in the FE model, which may lead to distortion of actual friction coefficient. In the future work, it would be advisable try to specify friction as a function of deformation, pressure, temperature and so on and track 
the response on the simulation model. There is also another approach where a friction model (sheet metal-lubrication-tool) is first created and then exported to the FEM software [9].

- Strain path depends on the friction coefficient. The higher friction coefficient, the higher levels of strains can be reached.

- The combination of PTFE foil + grease corresponds to friction coefficient value of $0.04-0.05$, which is confirmed by FE simulation.

Acknowledgement: This paper is the result of the implementation of projects VEGA 1/0441/17 and APVV-14-0834.

\section{References}

[1] Brusilová A., Schrek A., Švec P. et al.: Deep-drawing process simulation for tailorwelded blanks with an elastic blankholder, Strength Mater., 85 (2017) 586-593.

[2] Lumelskij D. et al.: Detection of strain localization in Nakazima formability test experimental research and numerical simulation, Procedia Eng., 183 (2017) 89-94.

[3] STN EN ISO 20482. Metallic materials - Sheet and strip - Erichsen cupping test, 2003.

[4] STN EN ISO 12004-2. Metallic materials - Sheet and strip - Determination of forming limit curves. Part 2: Determination of forming-limit curves in the laboratory, 2008.

[5] Larsson M., Mattiasson K., Sigvant M.: Some observations on failure prediction in sheet metal forming, 6h European LS-DYNA Users' Conference, 2007, pp. 93-102.

[6] Situ Q., Jain M, Metzger D.: Determination of forming limit diagrams of sheet materials with a hybrid experimental-numerical approach, Int. J. Mech. Sci., 53 (2011) 707-719.

[7] Slota J., Jurcisin M., Spisak E. et al.: Experimental FLC determination of high strength steel sheet metal, Acta Metall. Slovaca, 18 (2012) 200-209.

[8] Mattiasson K., Jergéus J., DuBois P.: On the prediction of failure in metal sheets with special reference to strain path dependence, Int. J. Mech. Sci., 88 (2014) 175-191.

[9] Pilthammar J., Sigvant M., Kao-Walter S.: Introduction of elastic die deformations in sheet metal forming simulations, Int. J. Solids Structures, 131 (2017) in press, https://doi.org/10.1016/j.ijsolstr.2017.05.009.

[10] Hol J., Meinders V.T., Geijselaers H.J.M. et al.: Multi-scale friction modeling for sheet metal forming: The mixed lubrication regime, Tribology Int., 85 (2015) 10-25. 


\section{WPŁYW WARUNKÓW TARCIA NA LOKALIZACJE USZKODZENIA BLACHY ALUMINIOWEJ AA5754 W TEŚCIE NAKAJIMA}

\section{Streszczenie}

W pracy przedstawiono numeryczne i eksperymentalne badania wpływu tarcia na lokalizację uszkodzeń w teście Nakajima. Symulację numeryczną testu przeprowadzono przy użyciu komercyjnego jawnego dynamicznego kodu FE. Wyniki uzyskane z symulacji FE porównano z danymi doświadczalnymi. W badaniach eksperymentalnych wykorzystano system ARAMIS do optycznej korelacji obrazu 3D. Lokalizacja uszkodzenia próbki wykazała zależność od warunków tarcia. Badania potwierdziły, że położenie pęknięcia w pobliżu środka próbki, zgodnie z wymaganiami normy ISO, można uzyskać dla niskich wartości współczynnika tarcia. Do oszacowania rzeczywistej wartości współczynnika tarcia w teście odkształcalności według Nakajima zastosowano symulację numeryczną połączoną z analizą odwrotną.

Słowa kluczowe: test Nakajima, tarcie, droga odkształcenia, uszkodzenie, symulacja FE

DOI: $10.7862 / \mathrm{rm} .2018 .05$

Otrzymano/received: 20.04 .2017

Zaakceptowano/accepted: 12.12.2017 